\title{
Exploring the Various Cultural Practices in Indian Writings
}

\author{
P. Pandia Rajammal, S. Rajkumar
}

\begin{abstract}
Culture is a community or set or group of people that has similar experience in which the inidividuals belonging to it perceive the universe. It constitutes aggregates of people based on various factors such as race, religion, nationality, gender, class, etc.. Indian tradition is one of the oldest and unique in the world. It combines the diverse linguistic and cultural tradition which exists within the country. Indian writers like Vikram Seth, Jhumpa Lahiri, Salman Rushdie, Vikas Swarup, David Davidar, Rohinton Mistry express opinions to their nations through history, tradition, culture and other controversial yet important problems in their fictions. This paper focuses on the issue of multiculturalism and cultural assimilation in literature. Lahiri has shown the need to go beyond the man made boundaries like culture, religion, race and nation acknowledge the universal aspects of human through her writings. The novel, Lowland reflects the globalised, multicultural and transnational culture.
\end{abstract}

Keywords: Assimilation, Cultural, Globalised, Multiculturalism, Transnational, Universal

\section{INTRODUCTION}

Culture is a prime system to discover, integrate and emphasize the national identity of India. Culture reflects in every activity of humans which governs their life and makes them live in Indian civilisation. The culture of India is based on its strong social system, family values and their lifestyle. Though India has a variety of cultures, traditions, practices, religions, languages, heriatges, it stands for unity in diversity. English Indian writing is an inevitable part of the literary and cultural studies in India. It projects the multi-dimensional complexity in the composition of the languages in India. Unity in the highest possible diversity of the society of India is a fact that is to be appreciated and cherished in a highly multicultural society of it.

\section{MULTICULTURALISM}

Multiculturalism can simply be said a perception to better comprehend and view the human life in a society. Humans are generally highly rooted to their culture and live within a pre-structured world in order to maintain their social relationships systematically. Since everyone realizes a constrained range of human capabilities and emotions, generally the society needs other cultures of various other societies to aid it to comprehend more, increase the moral,

Revised Manuscript Received on December 20, 2019.

P. Pandia Rajammal*, English department, Kalasalingam Academy of Research and Education, Krishnankoil, Tamil Nadu, India. pandiarajammal.p@klu.ac.in

S. Rajkumar, English department Kalasalingam Academy of Research and Education, Krishnankoil, Tamil Nadu, India. s.rajkumar@klu.ac.in intellectual boundaries of itself and so on. Most importantly every culture gives a contiguous string of arguments between its tradition and strands of thoughts that it implies or inherits.

Cultures expand as a result of unconscious and conscious interactions with a lot of other cultures that are possible to be interfered and influenced with and slowly get their own distinguished and signature identity that is quite multicultural in terms of their composition and roots. This can be obviously seen in the fiction of a lot of contemporary Indian Writers in English like Salman Rushdie. The Perspectiveness of Multiculture, inescapability and desirability of culturalism are the focal points in Rushdie's The Moor's Last Sigh, Midnight's Children, Shame, The Satanic Verses and The Enchantress of Florence. There was a high revolution in terms of cross cultural identities which clearly helped the 1980's and 1990's that experienced renaissance in the Indian Writing in English especially with the invasion of multiculturalism led by Salman Rushdie in his novel Midnight's Children in 1980, which was later concatenated by other comtemporary Indian writers in English. Earlier writers like Nirad C Choudhary, R.K. Narayan, Mulk Raj Anand and Raja Rao used English in its traditional and Eurocentric form whereas Rushdie started a new trend in writing and also in being an ambassador for multiculturalism.

Arundhati Roy's The God of Small Things describes a lot of social values of the Indian society. It clearly captures the Indian culture. The story basically deals with the exploitation of caste. The story revolves around the love between two individuals, Ammu and Velutha, who belongs to the untouchables. This novel also shows the caste and the gender bias, which are followed as a part of the early culture.and its values just after the colonialism in India. The colonial has left many effects in India. One of it is the cultural transformation. The colonizer culture has influenced some cultural practices of India. It has made Indians to consider colonizer's culture as more valuable than theirs. Aravind Adiga's The White Tiger emphasizes some of the important problems of Indian society like discrimination based on culture and caste and depreciation of cultural and traditional Indian values and fanatic nature of the majority of Indian societies towards the west. It tells that the easterners' minds are dominated by the foreign cultures. Starting from languages, life styles, dressing, etc., are regarded as issues for cultural degradation.

In Rushdie's Midnight Children, multiculturalism creates a new place where one cannot be a unique 
individual, rather one that shares elements from different cultures combined and through questions regarding family, heritage, symbolism of names and the allegorical representation of India's culture.The protagonist, Saleem asserts that he is breaking apart, struggling throughout the novel to prevent his imminent end. He realizes and accepts his new condition. Terms like class, nation and purity of race may be viewed with criticism through the theme of illegitimacy that characteristics Saleem's background. He was born to a Hindu mother and Christian father, later on nourished by Muslim parents, the protagonist is enclosed by the three major ethnic and religious group: Hinduism, Christianity, Islam. This mixture of cultures bestows him with plural identities and can be regarded as symbol for post-colonial India, due to fact that his birth concurs with that of modern nation, he grows, evolves and breaks into fragments, actions that mimic the faith of India. Rushdie underlines the fact that the glory of India is acquired through multicultural experience and that the biggest threat to the country is the threat toward the ideals of multiculturalism.

Culture is what that is said to give the meaning to a literary text. It is always very difficult to exactly understand and analyse the literary text without bearing the cultural aspects behind it. Bill Ashcroft and Pal Ahluwalia state that a community's economic, social, religious and political practices comprise its culture and every single aspect of them helps to understand a text. The identity of a text is generally formed by the cultural aspects associated with it. They also say that culture is both a function and source of identity for a given community (1).

The works of Jhumpa Lahiri represent the Indian culture and society. The Indians who were exposed to new cultures, in turn adopted and began to influence the other cultures. The same was obvious in case of the Indians in other countries. Michel Bruneau comments that the members of the diaspora no longer have their material relationship to their corresponding origin by immigration. Instead, through their memory, they can preserve their cultural relationship. Territoriality always continues to be an important factor when it comes to adapting to a new place in a host country oneself (2).

The backbone of the works of of Lahiri is her concern for the heritage of India. Taylor Shea descibes this fact with the following words: Lahiri uses her cultural background as an Indian American to create plots and characters that express the juxtaposition in her own life. She builds a balanced representation of her cultural group (3).

The Lowland is significant in accordance to the concept of multiculturalism. In this novel, Subhash loses his Indianness when he meets Holly. In the beginning, he falters to mix with Holly. He was not able to see a married life with Holly since the age difference between them was 10 years. Yet in due course, they become closer and gets sexually involved with her. He even replies positively when Holly askes if he would return to Calcutta after his degree with her. In fact, such type of closeness was not much of a common thing in India those days. He thinks that it will be really difficult for him to return

to India along with her. His assimilation with American culture looks to complete when he dreams to be like Narasimhan, who has am American wife and children, forming a stereotype to him. In accordance with the age-old traditions of India, in a family, the wife is generally expected to have meal after her husband has had his meal. In contrary, Gauri needs not to wait for Subhash.

Bela follows American culture. Unlike Gogol, Sonia, Lilia, Usha and Akash, Bela has no one to teach her Bengali language and culture. She had no one to teach her the Indian culture and no one to teach her to adhere to it. She totally did not have any idea about the life in Calcutta. Despite she being taken to Calcutta by Subhash, she does not get any like towards it. In the end, she grows to be a multicultural personality. Her physical appearance without any surprises resembles her grandparents yet later in her life, her Indian side pops out when she actually values the sacrifice of her uncle. She thinks "She [Bela] will never marry, she knows this about herself. The unhappiness between her parents: this has been the most basic awareness of her life" (4).

Bela does not desire to go in her mother's way. Subhash, who is similar to Gogol has many sexual relationships with women. Initially, he was with Holly. Later, he marries Gauri. Then, when Gauri abandons him, despite being old, he marries Elise Silva, who was Bela's history teacher. It is also being said that the relationships are not for the mere sexual gratification but for the sake of having homely and safe feelings. Similarly, Gauri, despite being new to the American culture, becomes no way lesser in terms of culture adaptation than Subhash. In fact, she started a Lesbian relationship with Lorna, who was graduate student from the University of California.

Durga Pujo has a special role in Lahiri's works. It has been mentioned in The Namesake. In The Lowland, it has a very special role since is linked with Udayan's death. Throughout Tollygunge, across Calcutta and almost the entirety of West Bengal, people woke up even in the darkness to do that is said that it was to invoke Durga with her children to descend to Earth. The readers witness that: For ten days after his death there were rules to follow. She did not wash her clothes or wear slippers or comb her hair. She shuts the door and the shutters to preserve whatever invisible particles of him floated in the atmosphere. She slept on the bed, on the pillow Udayan had used and that continued to smell for a few days of him (4).

Days of Durga Pujo and death rites run simultaneously. The days of Pujo arrive from: Shashthi, Saptami, Ashtami, Navami. It was simple - celebrations are in the city and the home was full of seclusion. During which, the vermillion of Gauri was washed clean from her hair, the iron bangle in her wrist was removed. As a widow she has not weared any ornaments. Gauri was just twenty-three years old. A priest arrived after eleven days to complete the final rituals. Udayan's portrait was framed and kept against the wall in tuberoses, inside the house. 
Gauri was not able to even look at the photo. She attended the ceremony, her wrists bare. "If anything happens to me, don't let them waste money on my funeral, he'd once told her. But a funeral took place, the house filled with people who'd known him, family members and party members coming to pay their respects. To eat dishes made in his honour, the particular foods that he had loved" (4).

Her in-laws began to eat fish and meat again, as soon as the seclusion and the mourning period ended but Gauri had not yet been allowed to eat as them. She had to only wear white saris and not the coloured ones like others. The majority of the widowed women were almost thrice as the age of her. "Dashami came: the end of Pujo, the day of Durga's return to Shiva. At night the effigies that had stood in the small pandal in their neighbourhood were taken to the river to be immersed. It was done without fanfare this year, out of respect for Udayan."(4). The Lowland also describes some of the common day-to-day beliefs. Bijoli teaches Bela about various Indian habits such as eating dal, rice and other food items when she visits Calcutta, accompanied by Subhash. As expected, Bela was not happy when she came to know that girls are mostly not allowed to roam in the city alone. The Lowland is also a tragic novel. In no matter of time, Udayan's act which was noble, turns out as a terrorist one, which gets him killed and his family disturbed. Subhash marries widow of Udayan and then takes her to America, which was regarded as something of a sacrifice from Subhash. On the other hand, Gauri devalues Subhash's sacrifice and abandons Subhash and her daughter, Bela alone. Bela later gets disappointed for her mother, when she understands what had happened.

Subhash tries to convince Udayan not to get involved in the movement of Naxalite. He advises Udayan to think of their parents. Udayan is highly cared by Subhash. When Subhash is in America, he gets a letter of Udayan from India, "Subhash reread the letter several times. It was as if Udayan were there, speaking to him, teasing him. He felt their loyalty to one another, their affection, stretched halfway across the world. Stretched perhaps to the breaking point by all that now stood between them, but at the same time refusing to break."(4). Udayan's death was sorrowful for a lot of people. Espacially Gauri's reminiscences of Udayan can deeply move the readers. "She had married Subhash as a means of staying connected to Udayan. But even as she was going through with it she knew that it was useless, just as it was useless to save a single earring when the other half of the pair was lost" (4).

Subhash decides to marry Gauri as a help to his brother, which he actually ended up doing. Subhash's love for Bela has a unique place in the novel. Gauri ends up leaving Bela but Bela in turn does not follow her mother's way. She gets pregnant before her marriage. However, she asks Subhash to take care of the child. Other than her name, Bela's complexion is another link to the Indian in her. Despite not looking similar to her parents, she was more like her actual or her paternal grandmother. She is not much privileged with respect to the general concept of mother's love but at the same time, she does not want to do what her mother did to her. She says to Subhash that she wants to keep her child, despite getting pregnant before marriage and wants to give birth to the child. After the birth of Megna, Bela starts to work in farms and leaves Megna alone which she later realises that the similar had happened in her life in the form of Gauri leaving her alone. She then starts to return early. "Bela's second birth felt more miraculous than the first. It was a miracle to him that she had discovered meaning in her life. That she could be resilient, in the face of what Gauri had done"(4). The confrontation between Gauri and Subhash reveals the distressed nature of Gauri's mind. Bela accuses Gauri for taking advantage of Subhash and also for abandoning her. Gauri, later tries to befriend Meghna. Bela, being furious over Gauri, asks her child to move away and asks Gauri to get out of her sight.

\section{CONCLUSION}

Lahiri's works entirely, describe the nature of multicultural society. In general cases of Indian Americans, the first generation try to maintain their Indianness by preserving some of their habits, culture and tradition whereas the later generations have quite a lot of issues with their unclear identities, mixed cultures and tradition. Thus they are more multicultural than their parents in most of the cases.

\section{REFERENCES}

1. Ashcroft, Bill and Ahluwalia, Pal, Edward Said, London: Routledge, 2001, pp. 32

2. Bruneau, Michel, Diasporas, Transnational Spaces And Communities, ed. Bauböck, Rainer and Faist, Thomas, Diaspora and Transnationalism: Concepts, Theories and Methods, Amsterdam: Amsterdam University Press, 2010, pp. 48.

3. Shea, Taylor, 'Interpreter of Maladies: A Rhetorical Practice Transmitting Cultural Knowledge', Reason and Respect Vol. 4: Issue-1, 2008 , pp. 46.

4. Lahiri, Jhumpa, The Lowland, Noida: Random House, 2013.

5. Rushdie, Salman. Midnight Children. London: Picador. 1981

6. Roy, Arundhati, The God of Small Things, New Delhi: India Ink, 1997

7. Adiga, Aravind. The White Tiger. New Delhi: Harper Collins, 2008.

\section{AUTHORS PROFILE}

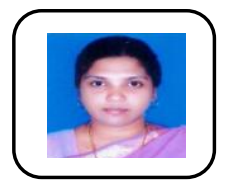

Dr. P. Pandia Rajammal, PhD., gruaduated at Madurai Kamaraj University, Tamil Nadu, India presented papers at National and Internationa Conference, published papers in Journal, Organied seminars and Guest Lectures, Guided PG projects and MPhil dissertations, working as an Assistant Professor at Kalasalingam Academy of Research and Education, Tamil Nadu, India.

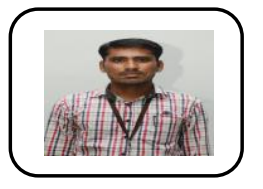

Mr. S. Rajkumar, M.A., M.Phil., graduated at Madurai Kamaraj University, Tamil Nadu, India, presented and published papers at International Conference, won the best teacher award, guided UG projects, working as an Assistant Professor at Tamil Nadu, India. 